\title{
The Influence of Oral Contraceptives on the Time- Integral of Thrombin Generation (Thrombin Potential)
}

Citation for published version (APA):

Rotteveel, R. C., Roozendaal, K. J., Eijsman, L., \& Hemker, H. C. (1993). The Influence of Oral

Contraceptives on the Time-Integral of Thrombin Generation (Thrombin Potential). Thrombosis and Haemostasis, 70(6), 959-962. https://doi.org/10.1055/s-0038-1649707

Document status and date:

Published: 01/01/1993

DOI:

10.1055/s-0038-1649707

Document Version:

Publisher's PDF, also known as Version of record

\section{Please check the document version of this publication:}

- A submitted manuscript is the version of the article upon submission and before peer-review. There can be important differences between the submitted version and the official published version of record.

People interested in the research are advised to contact the author for the final version of the publication, or visit the DOI to the publisher's website.

- The final author version and the galley proof are versions of the publication after peer review.

- The final published version features the final layout of the paper including the volume, issue and page numbers.

Link to publication

\footnotetext{
General rights rights.

- You may freely distribute the URL identifying the publication in the public portal. please follow below link for the End User Agreement:

www.umlib.nl/taverne-license

Take down policy

If you believe that this document breaches copyright please contact us at:

repository@maastrichtuniversity.nl

providing details and we will investigate your claim.
}

Copyright and moral rights for the publications made accessible in the public portal are retained by the authors and/or other copyright owners and it is a condition of accessing publications that users recognise and abide by the legal requirements associated with these

- Users may download and print one copy of any publication from the public portal for the purpose of private study or research.

- You may not further distribute the material or use it for any profit-making activity or commercial gain

If the publication is distributed under the terms of Article $25 \mathrm{fa}$ of the Dutch Copyright Act, indicated by the "Taverne" license above, 


\title{
The Influence of Oral Contraceptives on the Time- Integral of Thrombin Generation (Thrombin Potential)
}

\author{
R. C. Rotteveel ${ }^{1}$, K. J. Roozendaal ${ }^{2}$, L. Eijsman ${ }^{3}$, and H. C. Hemker ${ }^{4}$ \\ From the Departments of ${ }^{1}$ Clinical Chemistry, ${ }^{2}$ Haematology, and ${ }^{3}$ Cardiopulmonary Surgery, Onze Lieve \\ Vrouwe Gasthuis, Amsterdam, and the ${ }^{4}$ Department of Biochemistry, University of Limburg, Maastricht, \\ The Netherlands
}

\section{Summary}

The thrombin potential (TP) has been defined as the time integral of (i.e. the area under) the thrombin generation curve. It has been shown that this parameter decreases with all types of anticoagulant treatment and increases with ATIII deficiency.

We evaluated the use of this parameter for detection of the hypercoagulative state known to accompany oral contraception.

In fresh frozen control plasma the TP could be determined with high reproducibility ( $n=82$, c.v. $2.9 \%$ ). The TP was linearly diminished by mixing fresh frozen plasma with prothrombin deficient plasma while a high coefficient of correlation was observed ( $r=0.997)$.

Women using oral contraceptives showed a significantly $(p<0.0001)$ higher TP $(\mathrm{TP}=569 \mathrm{nM} \cdot \min , \mathrm{SD}=55, n=17)$, compared to men or, to women not using oral contraceptives (TP $=484 \mathrm{nM} \cdot \min , \mathrm{SD}=52, \mathrm{n}=41$ ).

This suggests that the thrombin potential indicates the prethrombotic state known to exist in women using oral contraceptives.

\section{Introduction}

Overall coagulability is usually assessed by means of a clotting time in one of its many variations. This always amounts to measuring the lag time before a burst of thrombin occurs (1).

The clotting time gives no direct information, either on the amount of thrombin generated or on the time during which it can act.

The Thrombin Generation Test has proven its value in the laboratory research on the mode of action of anticoagulants (2-5).

It has been suggested that the time integral of the thrombin generation curve, i.e. the area under that curve, would be a good parameter for the amount of "enzymatic work" (haemostatic or thrombotic) that thrombin generated in clotting blood can do $(6$, 7). This parameter has been called the thrombin potential (TP) (8).

It has been shown $(9-12)$ that the TP decreases as a result of heparin treatment, with oral anticoagulation and by a variety of other anticoagulants (Dermatan sulfate, Hirudin, Lactobionic acid and various low molecular weight heparins). The thrombin potential therefore, is candidate to become a general indicator of hypocoagulability.

We wanted to investigate whether the thrombin potential would be a practical test in a hospital laboratory, and whether it could detect the relatively subtle hypercoagulative state that accompanies the use of oral contraceptives (7). Therefore, we

Correspondence to : H. C. Hemker, Dept. of Biochemistry, University of Limburg, 6200 MD Maastricht, The Netherlands evaluated the Thrombin Generation Test, using fresh frozen human plasma, for reproducibility and linearity with respect to prothrombin concentration. The distribution of TP values was established for women using and not using oral contraceptives and for men.

\section{Materials and Methods}

\section{Volunteers}

Informed consent was obtained from 58 apparently healthy volunteers without any history of coagulation disorders.

The group consisted of 17 women using oral contraceptives (type sub50, estrogen: ethinyl estradiol), 18 women not using any and 23 men.

Two women, one from each group, were followed for about one month in order to see whether the TP varies during the menstrual cycle. Blood was sampled from the one taking oral contraceptives on days $1,2,8,10$, 20,27 of the menstrual cycle ( 28 days); from the other on days $1,4,7,12$, 14, 17, 19 (cycle 26 days).

\section{Collection and Processing of Blood Samples}

Blood was collected on $0.13 \mathrm{M}$ trisodium citrate: nine parts of blood to one part citrate solution. After centrifugation $(2000 \mathrm{~g}, 20 \mathrm{~min}$, room temperature) the plasma was collected and when necessary stored at $-20^{\circ} \mathrm{C}$ until analysis. All samples were analyzed for prothrombin time (PT), activated partial thromboplastin time (aPTT), antithrombin III (ATIII) and thrombin potential (TP)

\section{Reagents and Assays}

Reptilase was obtained from Boehringer Mannhcim (Mannheim, Germany), human thromboplastin from Behring (Behringwerke AG, Markburg, France), Factor II deficient plasma from Laboratoires Stago (Asnières, France). Thrombin substrate \$2238 came from Kabi Diagnostica (Mölndal, Sweden). All reagents were prepared according to the manufacturers' instruction.

PT and aPTT values were obtained by means of Boehringer Mannheim Calcium-Thromboplastin and PTT Reagent, no coagulometer was used. ATIII values were obtained by means of reagents from Kabi Diagnostica.

As control material, fresh frozen ACD plasma was obtained from the Central Laboratory of the Bloodbank of Amsterdam.

The fresh frozen plasma was derived from one donor, collected in citrate anticoagulant with the same end-concentration as volunteers' test plasmas. The frozen material was allowed to reach room temperature in about $5 \mathrm{~h}$, thoroughly mixed, distributed in $1.5 \mathrm{ml}$ portions and restored at $-20^{\circ} \mathrm{C}$. All chemicals were of the highest grade commercially available. All solutions werc made in $18 \mathrm{Mohm} \cdot \mathrm{cm}$ de-ionized water.

\section{Determination of Thrombin Generation in Plasma}

Defibrinated plasma was obtained by mixing plasma 50:1 with reptilase solution, allowing clot formation for $10 \mathrm{~min}$ at $37^{\circ} \mathrm{C}$ and keeping the clotted plasma at $0^{\circ} \mathrm{C}$ for $10 \mathrm{~min}$. The fibrin thus formed was removed by winding on a small plastic spatula.

Thrombin potential values were measured as described in (6) and determined in duplicate. 


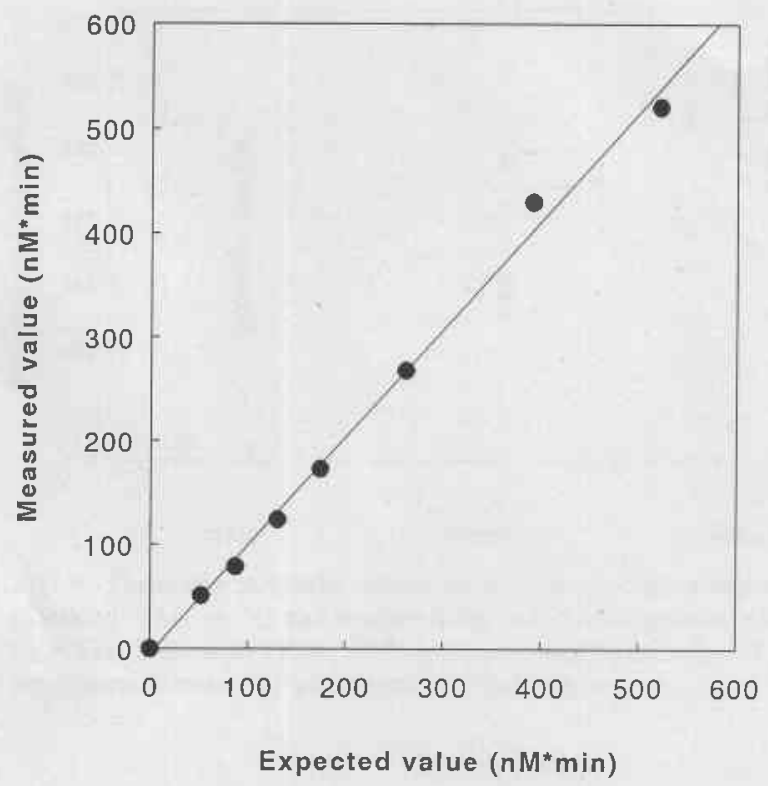

Fig. 1 Linearity with respect to prothrombin of fresh frozen control plasma diluted with factor II deficient plasma

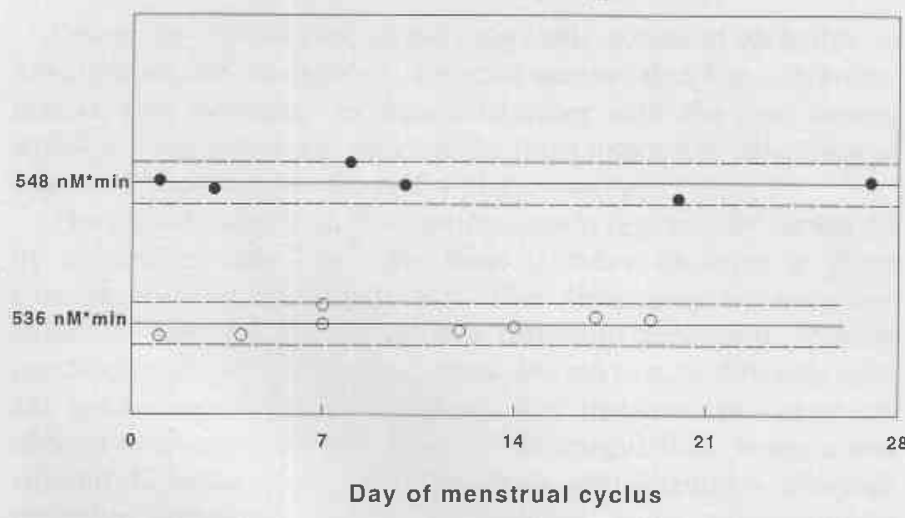

Fig. 2 The thrombin potential during the menstrual cycle. Open circles represent TP values of a woman not using oral contraceptives with a menstrual cycle of 26 days. Closed circles represent TP values of a woman taking sub-50 oral contraceptives. The broken lines represent 2 SD limits derived from reproducibility experiments $(\mathrm{SD}=16 \mathrm{nM} \cdot \mathrm{min})$

\section{Linearity with Respect to Prothrombin Concentration}

Linearity experiments were performed with defibrinated control ACD plasma mixed with defibrinated factor II deficient plasma in order to get defined ratios of prothrombin concentration and minimal changes in other plasma proteins. Expected values werc calculated from the TP of the undiluted control material, determined 4 times, and the dilution factor. TP values of mixed plasmas were measured in duplicate.

\section{Statistics}

Statistical analysis was performed with Statgraph 5.0 software (Statistical Graphics Corporation, USA). Values are means ( \pm SD) unless stated otherwise. Least square linear regression analysis was used in order to evaluate linearity. Different groups of volunteers were compared using the Mann-Whitney $U$ test. A p-value less than 0.01 was considered to be significant.

\section{Results}

\section{Reproducibility}

To evaluate the interassay reproducibility of the determination of the thrombin potential we measured the TP of a fresh frozen plasma 82 times over a period of 3 months.

The mean value was $541( \pm 16) \mathrm{nM} \cdot \min$ with a coefficient of variation of $2.9 \%$. The intra-assay reproducibility was calculated from the duplicates according to (13). The standard deviation of the differences was $14 \mathrm{nM} \cdot \min$, which is $2.6 \%$.

\section{Linearity with Respect to Prothrombin Concentration}

As described in the introduction, the TP is diminished by all known anticoagulants $(6,10-12)$. Ceteris paribus, it should be linear with respect to the prothrombin concentration in plasma (9). This assumption is implicit to the use of the area under the thrombin generation curve as a means of prothrombin estimation (ref. 14, p. 165, p. 353). We performed this linearity experiment to see whether the results from a research laboratory (9) were reproducible in our hospital laboratory.

As a test of variable TP values we determined the TP in a series of plasmas in which the prothrombin concentration was varied by mixing a control and a prothrombin deficient plasma. See Fig. 1.

Linear regression analysis was close to the line of identity: $\mathrm{TP}_{\text {measured }}=1.048( \pm 0.036) \cdot \mathrm{TP}_{\text {expected }}-6.744( \pm 10.0)$.

The coefficient of correlation was 0.997 .

\section{Thrombin Potential During the Menstrual Cycle}

To investigate any possible variance associated with the menstrual cycle, blood was taken from two women, one taking oral contraceptives, at different points in the menstrual cycle.

The TP time variance for both women during the menstrual cycle remained within the $2 \mathrm{SD}$ range of the assay (Fig. 2). The coefficients of variation were $3.3 \%$ and $2.9 \%$ respectively.

\section{Healthy Volunteers}

Blood was taken from 58 healthy volunteers, forming three groups: men $(n=23)$, women using oral contraceptives $(n=17)$ and women not using oral contraceptives $(n=18)$.

The thrombin potential, PT, aPTT and ATIII values were determined. The mean values are presented in Table 1 and Fig. 3.

Table 1 Mean thrombin potential, PT, aPTT and ATIII values of three groups of volunteers; men, women not using and using oral contraception

\begin{tabular}{|c|c|c|c|c|c|}
\hline & $n$ & $\begin{array}{l}\mathrm{TP}(\mathrm{SD}) \\
\mathrm{nM} \cdot \min \end{array}$ & $\begin{array}{l}\mathrm{PT}(\mathrm{SD}) \\
\mathrm{s}\end{array}$ & $\begin{array}{l}\text { APTT (SD) } \\
\text { s }\end{array}$ & $\begin{array}{l}\text { ATIII (SD) } \\
\%\end{array}$ \\
\hline Men and women NOC & 41 & $484(52)$ & $13.4(0.4)$ & $35.7(3.2)$ & $126(17)$ \\
\hline $\begin{array}{l}\text { Men } \\
\text { Women NOC } \\
\text { Women OC }\end{array}$ & $\begin{array}{l}23 \\
18 \\
17\end{array}$ & $\begin{array}{l}470(48) \\
501(54) \\
569(55)^{* * *}\end{array}$ & $\begin{array}{l}13.6(0.8) \\
13.1(0.6) \\
12.9(0.7)\end{array}$ & $\begin{array}{l}36.5(3.2) \\
34.7(3.0) \\
35.3(2.9)\end{array}$ & $\begin{array}{l}118(15) \\
133(17)^{*} \\
114(17)\end{array}$ \\
\hline
\end{tabular}

OC: using oral anticonceptives; NOC: not using oral anticonceptives.

* $p<0.01$ comparing women not using oc. with women using oc. and men.

*** $p<0.0001$ comparing women using oc. with women not using oc, and men. 


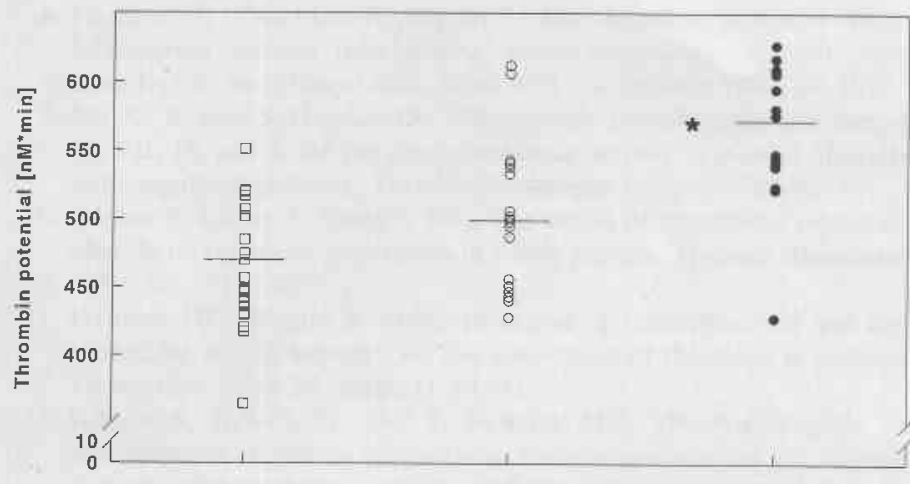

male female (-) female $(+)$

Fig. 3 Thrombin potential values of men $(n=32)$, women not using (female $[-])(n=18)$ and women using oral contraceptives, (female $[+])$ $(n=17)$. The mean TP for each group is indicated by a line. $* p<0.0001$ comparing female $(+)$ with female $(-)$ and men.

\section{Discussion}

Given the central role of the enzymatic action of thrombin in haemostasis and thrombosis, one can assume that the concentration of free thrombin in plasma together with the time during which it is enzymatically active is the most important indication of hyper- or hypocoagulability of a plasma sample.

The global activity of the clotting system is generally measured by a clotting time, i.e. the time it takes to form a given concentration of thrombin (1). This time may or may not correlate with the amount of free thrombin generated. Usually conditions are chosen so that is does, but up to now different tests are needed for different situations. For instance, two tests are needed to monitor the two types of anticoagulation, heparin and vitamin $\mathrm{K}$ antagonists, although both anticoagulants diminish thrombin enzymatic activity. In addition, some anticoagulants (e.g. dermatan sulphate) escape detection by any current type of clotting tests.

The Thrombin Generation Test monitors the end result of thrombin formation and inactivation processes. Notably the concentration-time integral of the thrombin generation curve will reflect the amount of "enzymatic work" that generated thrombin can carry out. It has been shown that a decreased thrombin potential accompanies both heparin administration and treatment of vitamin $\mathrm{K}$ antagonists (9-12).

We investigated whether the thrombin generation test could detect the hypercoagulative state known to accompany the use of oral contraceptives. We found a good inter- and intra-assay reproducibility (c. v. resp. $2.9 \%, 2.6 \%$ ). We expect this result to improve with a fully automated assay. The linearity of the assay with respect to prothrombin was evident in the near-identity line found in the regression analysis of the diluted samples.

From the finding that the TP variance during the menstrual cycle was within the 2 SD uncertainty of the assay, we concluded that the monthly cycle was of no significant influence on the TP (Fig. 2).

The thrombin potential is indeed influenced by use of oral contraceptives; the TP increases $(p<0.0001)$ (Fig. 3).

To our knowledge, the Thrombin Generation Test seems to be the first overall coagulation assay that can monitor the thrombogenic action of oral contraceptives (15 and references therein).

The procoagulant effect of oral contraceptives was not reflected in PT or aPTT values. Conforming literature (15-18) we found a lower mean ATIII value in women using oral contraceptives (Table 1). Future experiments will show whether there is a relation between ATIII concentrations and TP values. In contrast to ref. 15, no statistical difference was observed between ATIII values of women using oral contraceptives and men.

Haemostasis is regulated by the delicate balance between procoagulant and anticoagulant mechanisms. Disturbance in this balance may lead to excessive bleeding tendency or increased risk of thrombosis.

It seems that the TP reliably indicates small changes in this balance.

On the other hand there is also the balance between fibrin formation and degradation, which may be disturbed as well in persons using oral contraceptives. Recently it has been reported (19) that plasminogen levels are significantly higher in pill-taking females $(n=694)$ compared to men $(n=5506)$ or non pill-taking females $(n=1724)$.

In females taking oral contraceptives the phenomenon of a higher plasminogen level might reflect a compensatory reaction to a higher thrombin potential; nature's attempt to maintain the balance in fibrin-forming and fibrin-degradation processes. We think the TP does not reflect this balance.

Further studies will have to show whether the TP has any predictive value for the occurrence of thrombosis.

We conclude that a coagulation test which demonstrates an increased coagulability in a group of women using oral contraceptives, known to induce a mild prothrombotic tendency, is a promising tool in determining the hitherto relatively elusive "hypercoagulant state" that may predict a thrombotic tendency. For routine use in coagulation laboratories this test need to be automated, e.g. by continuous registration of thrombin amidolytic activity (20).

\section{Acknowledgements}

The authors wish to thank all volunteers for blood donation, T. E. de Groot and N. J. van den Bos for technical assistance. We also want to thank S. Béguin, E. H. Slaats, R. N. M. Weijers, S. Wielders and J. C. Kennedy for valuable discussions as well as $\mathbf{J}$. Oosting for advice on statistics.

\section{REFERENCES}

1. Hemker HC, Béguin S. How to measure the relevant effect of anticoagulant treatment of the coagulability of plasma. In: Thrombosis and its management. Poller L, Thomson JM, eds. Edinburgh: Churchill Livingstone 1993; 3-14.

2. Pieters J, Willems G, Hemker HC, Lindhout T. Inhibition of factor IXa by antithrombin III/heparin during $\mathrm{X}$ activation. $\mathrm{J}$ Biol Chem 1988; 263: 15313-8.

3. Béguin S, Mardiguian J, Lindhout T, Hemker HC. The mode of action of low molecular weight heparin preparation (PK10169) and two of its major components on thrombin generation in plasma. Thromb Haemostas 1989; 61: 30-4.

4. Hemker HC, Choay J, Béguin S. Free factor $\mathrm{Xa}$ is on the main pathway of thrombin generation in clotting plasma. BBA 1989; 992: 409-11.

5. Ma Xi, Béguin S, Hemker HC. Importance of factor-IX-dependent prothrombinase formation - the Josso pathway - in clotting plasma. Hemostasis $1989 ; 19$ : 301-8.

6. Hemker HC, Willems GM, Béguin S. A computer assisted method to obtain the prothrombin activation velocity in whole plasma independent of thrombin decay processes. Thromb Haemostas 1986; 56: 9-17.

7. Von Kaulla E, Droegemueller W, Aolie N, von Kaulla KN. Antithrombin III depression and thrombin generation acceleration in women taking oral contraceptives. Am J Obstet Gynec 1971; 109: $868-73$. 
8. Hemker HC, Wielders S, Béguin S. The thrombin potential. From Fraxiparine, second international world symposium. Recent pharmacological and clinical data. New York: Schattauer 1990; 89-101.

9. Ma Xi, Béguin S, Hemker HC. The relative importance of the factors II, VII, IX and X for the prothrombinase activity in plasma of orally anticoagulated patients. Thromb Haemostas 1989; 62: 788-91.

10. Béguin S, Choay J, Hemker HC. The action of a synthetic pentasaccharide on thrombin generation in whole plasma. Thromb Haemostas 1989; 61: 397-401.

11. Hemker HC, Béguin S. Mode of action of unfractionated and low molecular weight heparins on the generation of thrombin in plasma. Hemostasis 1990; 20 (suppl 1): 81-92.

12. Béguin S, Kessels H, Dol F, Hemker HC. The consumption of antithrombin III during coagulation, its consequences for the calculation of prothrombinase activity and the standardization of heparin activity. Thromb Haemostas 1992; 68: 136-42.

13. Bland JM, Altman DG. Statistical methods for assessing agreement between two methods of clinical measurement. Lancet 1986; 1 : 307-10.

14. Biggs R, MacFarlane RG. Human blood coagulation and its disorders. Oxford: Blackwell Scientific Publications 1953.

15. Fagerhol MK, Abildgaard U. Immunological studies on human antithrombin III. Scand J Haemat 1970; 7: 10-7.
16. Hedlin AM. The effect of oral contraceptives estrogen on blood coagulation and fibrinolysis. Thrombos Diathes Haemorrh 1975; 33: $370-8$.

17. Caine YG, Bauer KA, Barzegar S, ten Cate H, Sacks FM, Walsh BW, Schiff I, Rosenberg RD. Coagulation activation following estrogen administration to postmenopausal, women. Thromb Haemostas 1992; 68: $392-5$.

18. Robinson GE, Burren T, Mackie IJ, Bounds W, Walshe K, Faint R, Guillebaud J, Machin SJ. Changes in hemostasis after stopping the combined contraceptive pill; implications for major surgery. BMJ 1991; 302: 269-71

19. Tait RC, Walker ID, Conkie JA, Islam AM, McCall F, Mitchell R, Davidson JF. Plasminogen levels in healthy volunteers - influence of age, sex smoking and oral contraceptives. Thromb Haemostas 1992; 68: $506-10$.

20. Hemker HC, Wielders S, Kessels H, Béguin S. Continuous registration of thrombin generation in plasma, its use for the determination of the endogenous thrombin potential. Thromb Haemostas 1993; accepted for publication.

Received March 3, 1993 Accepted after revision August 24, 1993 